\title{
EGFR NP_005219.2:p.A750_E758del
}

National Cancer Institute

\section{Source}

National Cancer Institute. EGFR NP 005219.2:p.A750 E758del. NCI Thesaurus. Code C98568.

A deletion of nine amino acids from the epidermal growth factor receptor protein from the alanine at position 750 through the glutamic acid at position 758 . 